\title{
Typology and Audience Engagement of University Galleries
}

\author{
Eva Gartnerová
}

\author{
Eva Gartnerová, PhD \\ Tomas Bata University in Zlin \\ Faculty of Multimedia Communications \\ Univerzitní 2431 \\ 76001 Zlín \\ Czech Republic \\ e-mail: gartnerova@utb.cz
}

Muzeológia a kultúrne dedičstvo, 2021, 9:1:119-134

DOI: $10.46284 / \mathrm{mkd} .2021 .9 .1 .7$

\begin{abstract}
Typology and Audience Engagement of University Galleries
The main objective of this study is to analyse the environment and the processes of university galleries and their exhibition spaces, primarily on the territory of the Czech Republic and Slovakia. The historical development of university galleries and their role in society are briefly introduced. An important part of this research paper deals with the definition and typology of university galleries, followed by an analysis of their role and a discussion on the aspect of audience and public engagement. The study draws on research conducted by the author in the years 2016-2020 predominantly in the Czech Republic and Slovakia, described in detail in her doctoral thesis. The methodology of the research is mainly based on semi-structured interviews and study visits of the various institutions in question. The research paper brings forth the subject of university galleries and their role in the advancement of the academic cultural environment.
\end{abstract}

Keywords: university galleries, university museums, cultural management, audience engagement, experimental university spaces

\section{Introduction}

Since the beginning of the twenty-first century, university galleries and museums have enjoyed a resurgence of interest, which has naturally led to their growth. Important events that have indubitably contributed to this development include the foundation of the European network UNIVERSEUM in 2000 and the International Committee for University Museums and Collections (UMAC) under the International Council of Museums (ICOM) in 2001, the 2009 renovation and reconstruction of the Ashmolean Museum in Oxford, universally recognised as the first ${ }^{1}$ university museum in the world founded in 1683, and the renovation of the Musée des Arts et Métiers in Paris, which reopened its collections to the public in 2000. While the growing interest of the general public gives university galleries and museums a new direction, it also further stresses the need for official recognition by the international museum and gallery community. As is the case with other cultural organizations, the audiences of university galleries are becoming an ever more important part of the development strategies of these institutions.

This research is the first of its kind to propose a typology of non-collection-based university galleries. It can therefore serve as a starting point for researchers interested in this new and rapidly evolving discipline. The focus on the context of the Czech Republic and Slovakia is also

${ }^{1}$ The Ashmolean Story, accessed February 7, 2021, https://www.ashmolean.org/history-ashmolean 
unique, as little research on the topic has been conducted in the region of central Europe, in part due to the fact that most local university galleries were established in the past twenty years, and none of them possess any collections. This makes them undeserving of attention in the eyes of some, a misconception that this research paper sets out to tackle. Lastly, the research also proves the important role that non-collection-based university galleries play in publicuniversity interaction, interdisciplinary cooperation and artistic experimentation.

\section{Origin and Development of University Galleries}

University galleries experienced a gradual growth, and their origin and subsequent development towards actively engaging with their audiences is generally considered to have come about quite late. They first came into existence when the recently established art history departments of universities concentrated their collections into one place or when wealthy benefactors bequeathed their private collections to academic institutions. If we want to look for origins of art galleries in school settings outside of universities, newly emerging art academies of the seventeenth and eighteenth centuries deserve our attention. These academies would hold contests, organise exhibitions and house collections of both reproductions and originals of important works of art for educational purposes. To this end, they built picture galleries (pinacothecae), sculpture galleries (glyptothecae), plaster cast galleries (gypsothecae) or graphic art rooms. $^{2}$

Around the end of eighteenth and beginning of nineteenth century, these collections were made accessible in newly established academic picture galleries and museums or donated for public use in an effort to establish new museum-like institutions focused on art history. ${ }^{3}$ One of the most impressive academic picture galleries is The Paintings Gallery of the Academy of Fine Arts Vienna, which was established after Count Lamberg-Sprinzenstein donated his entire painting collection in 1822. ${ }^{4}$ Art schools also gradually incorporated exhibition halls, spaces where short-term exhibitions took place, which is exactly what Francis Haskell referred to when he talked about the "ephemeral museum". One such example illustrated by Haskell is when the Academy of Fine Arts Vienna revitalised a theatre inventory space and scenery depot to use it as exhibition and theatre spaces (1990-1995), cementing the local tradition of these spaces being used as a modern centre for education and the presentation of artistic production.

In the context of the historical development of university galleries, universities located in the United States play a specific role. Thanks to the fact that they operated on larger campuses and would often receive generous donations of significant museum collections from local benefactors, the development of university galleries in the US had a head start compared to Europe. The Yale University Art Gallery in New Haven, Connecticut, the oldest university gallery in the western hemisphere, was established in 1832. Prestigious university art collections tend to be called "galleries" in US terminology, and their placement on the campus usually corresponds with their esteemed status. ${ }^{6}$

\footnotetext{
${ }^{2}$ KROUPA, Jiří, personal communication, May 14, 2020.

${ }^{3}$ PEVSNER, Nikolaus. Academies of Art: Past and Present. United Kingdom: Cambridge University Press, 2014, p. 256-257.

${ }^{4}$ The history of The Paintings Gallery, accessed February 7, 2021 https://www.akbild.ac.at/portal_en/collections/ paintingsgallery/collection/history/the-history-of-the-paintings-gallery?set_language=en\&cl=en

${ }^{5}$ HASKELL, Francis (2000). The Ephemeral Museum: Old Master Paintings and the Rise of the Art Exhibition. Yale: Yale University Press, p. 22-49.

${ }^{6}$ KROUPA, Jiří, personal communication, May 14, 2020.
} 
New university galleries started emerging in Europe at the end of the nineteenth century in the form of galleries of art history, as this discipline rose to prominence around that time. These galleries were closely tied with the instruction of art history as well as research activities in the field. ${ }^{7}$ Of the more prominent European university art museums whose existence and legacy had an impact on the academic sphere and art history, the Ashmolean Museum is certainly worth a mention. It was established in 1683 at the University of Oxford to house a collection made up of the cabinet of curiosities donated to the university by Elias Ashmole. He envisioned for the museum to become a centre of practical research and learning based around its collections. Even today, research on collections is at the core of the museum's activities. Though originally established as a museum of natural sciences, the Ashmolean Museum broadened its focus towards art collections in the end of the nineteenth century, as first art history classes were taught at the university in 1870, followed later by the establishment of the Department of History of Art at the Faculty of History. This first ever university museum also became the first museum in the world to be open to the public. ${ }^{8}$

In the United States, a key development in the history of university museums and galleries was the establishment of the Princeton University Art Museum, founded in 1882. Today, it houses a remarkable collection ${ }^{9}$ of around 100,000 exhibits from various time periods and a number of culture areas, donated to the university in large part by its alumni. ${ }^{10}$ Another milestone in the development of university museums and galleries came with the 1852 manuscript of The Ideal Museum: Practical Art in Metals and Hard Materials by Gottfried Semper, ${ }^{11}$ in which he stresses the modern notion of an art museum, tied closely with the establishment of art academies, with the "museum" being considered conducive to the instruction of art. Semper further proposes that every museum be accompanied by an associated school, claiming that an ideal art museum must fulfill the role of public education. ${ }^{12}$ Subsequently, the Imperial Royal Austrian Museum of Art and Industry, known today as MAK, was founded alongside Vienna School of Arts and Crafts, while in the Czechoslovak context, the Museum of Applied Arts in Brno was established alongside the Secondary School of Arts and Crafts. Since the 1990s, the process of emergence of university galleries in the Czech Republic has been mostly connected to their development within art schools. ${ }^{13}$

In contrast to English-speaking countries, such as the United States, the Czech Republic and Slovakia have a very specific portfolio of university galleries, the typology of which will be introduced later on. They are exclusively non-collection-based, and their establishment can be traced back to the end of the twentieth century. They were founded not only with an aim

\footnotetext{
${ }^{7}$ PEVSNER, Academies of Art..., p. 160-176)

${ }^{8}$ The Ashmolean Story, https://www.ashmolean.org/the-ashmolean-story

9 The museum's European art collection includes works of art from the likes of Hieronymus Bosch, Albrecht Dürer, El Greco, Michelangelo, Rembrandt, Anthony van Dyck, Francisco Goya, Paul Cézanne, Édouard Manet, Claude Monet, Pierre-Auguste Renoir, Paul Gauguin, Vincent van Gogh, Edgar Degas, Henri de Toulouse-Lautrec, Amedeo Modigliani, Wassily Kandinsky, Jean Arp, Emil Nolde and Pablo Picasso, arguably a good example of a representative academic art museum.

${ }^{10}$ S. WOOD, Christopher. A History of Art History. United Kingdom: Princeton University Press, 2019, p. $252-266$.

11 SEMPER, Gottfried. The Ideal Museum: Practical Art in Metals and Hard Materials. Vienna: Schlebrügge, 2007. Začátek formuláře

${ }^{12}$ Frankenberg, Pablo. Museum Utopia. A Brief Architectural History of the Ideal Museum. In Art History Supplement, 2(3), May 2012, p. 23-26. Accessed at: https://www.vonfrankenberg.cc/site/assets/files/1072/museum_utopia_ahs.pdf.

${ }^{13}$ KROUPA, Jiří, personal communication, May 14, 2020.
} 
to showcase student projects and the works of academic staff but also with a vision to present young and up-and-coming authors who contribute to shaping current trends in the fields of fine arts and design. The oldest university gallery in the Czech Republic still in operation is considered to be the AVU Gallery, a gallery of the Academy of Fine Arts, Prague, which was established in 1993 as an exhibition space for students and has since broadened its scope. It was preceded only by the Czechoslovak Medium Gallery at the Academy of Fine Arts and Design, Bratislava. The period after the turn of the millennium is generally considered to be an era when the field of Czech university galleries experienced the largest boom.

In 2001, the UM Gallery was founded at the Academy of Arts, Architecture and Design in Prague, followed by the FFA Gallery (Galerie FAVU in Czech, originally known as Aula) at the Faculty of Fine Arts of Brno University of Technology, established in 2004. The Academy of Performing Arts in Prague opened its own gallery under the name of GAMU in 2008, while the Ladislav Sutnar Faculty of Design and Art of the University of West Bohemia followed suit with its own gallery in 2011. The field of university galleries in the Czech Republic achieved a new dimension with the 2016 opening of the Ústí nad Labem House of Arts at the Faculty of Art and Design of Jan Evangelista Purkyně University in Ústí nad Labem. Though currently the youngest of its kind in the country, G18 Gallery, established by the Faculty of Multimedia Communications of Tomas Bata University in Zlin, has also managed to garner attention in the academic sphere. Many other university galleries have emerged since the year 2000, some of which are no longer in operation and have since been replaced by new concepts or spaces (such as Armaturka Gallery in Ústí nad Labem). An important factor to consider when surveying the history of university galleries in the context of the Czech Republic and Slovakia is the fact that most of these countries' universities do not have a long enough history and tradition to have developed their own collections.

In the final years of the twentieth century, an international community centred around university museums and collections started to form and mobilise. Initially, these formations did not surpass the national level, as several countries founded their own national associations ${ }^{14}$ (for example in the UK, USA, South Korea and Brazil), but through networking and transnational cooperation, the first international associations emerged.

In Europe, two important networks focused on academic heritage and university museums were formed. UNIVERSEUM, also known as the European Academic Heritage Network, was established in 2000, while UMAC, the International Committee for University Museums and Collections, was set up in 2001. The establishment of these European international networks, resulting in closer cooperation and intensified communication efforts among their members, has improved the quality and, more importantly, the perception of university museums (and galleries) over the past twenty years. As Marta Lourenço, the current UMAC chair, pointed out in her speech at an ICOM meeting in Milan in 2019, awareness of university collections and museums has grown, mainly thanks to recognition by the international network ICOM. In the meantime, many collections and university museums have been reorganised, renovated, gradually made accessible and reintroduced into the teaching process or opened to the general public. New university galleries and museums are being created, and they are much more open

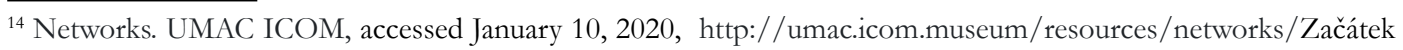
formuláře 
and better prepared to engage their university-based audiences or even the general public. ${ }^{15}$

\section{The Phenomenon of the University Gallery}

As mentioned earlier, two institutions concerned with university museums exist in the European context: UMAC and UNIVERSEUM. However, their definitions and information are too broad and general, and in their purpose they do not deal with purely artistic and designoriented non-collection-based galleries, but rather with the whole portfolio of university museums, which includes such disciplines as biology, history, psychology, archaeology, etc. The category of non-collection-based university galleries will be discussed later on.

In order to better understand and contextualise university galleries, it is necessary to describe the role and function of the International Council of Museums. ICOM is an international organization of museums and museum professionals, first established in the years 1946-1947, "committed to the research, conservation, continuation and communication to society of the world's natural and cultural heritage, present and future, tangible and intangible." ${ }^{\prime 6}$ ICOM is the only global organization in the field of museums.

The Czech Republic also has its own ICOM national committee, founded in 1994 as a successor to the Czechoslovak committee, which was one of the 14 founding members in 1946. The mission of the Czech committee is mainly to support the involvement of Czech museum and gallery professionals in international communities.

ICOM's membership is quite large, and its conferences and congresses are visited by thousands of gallery representatives from all around the world. Apart from national committees, ICOM has also set up a host of international committees, dedicated to specific areas of expertise in the field of museology, UMAC being the most relevant for university galleries. The International Council of Museums Committee for University Museums and Collections is one of the two significant international networks that contribute to the development and support of university galleries and museums. It was founded by an international group of professionals active in university galleries who had understood that university museums and galleries faced a number of challenges, which often had to do with the fact that they operated under higher education institutions. The first international UMAC conference took place in Barcelona in 2001. The current committee chair is Marta Lourenço. ${ }^{17}$

Although ICOM sees university galleries as one of the categories within university museum, it has recently shifted its definition of a "museum", something that will definitely have an impact on the perception of galleries, too. A generally accepted definition of the term "university gallery" has not been proposed as of yet.

\footnotetext{
${ }^{15}$ LOURENÇO, Marta. Defining the UNIVERSITY MUSEUM today: Between ICOM and the 'third mission'. accessed July 10, 2019, http:/ / umac.icom.museum/defining-the-university-museum-today-between-icom-and-the-third-mission

${ }^{16}$ ICOM Museum definition, accessed August 29, 2019, https://icom.museum/en/about-us/missions-and-objectives/

${ }^{17}$ UMAC: International council of museums committee for university museums and collections, accessed July 23, 2019, http://umac.icom.museum/
} 
In a follow-up personal communication ${ }^{18}$ regarding the redefining of museums on April 24 2019, Marta Lourenço said that we first need to define all types of institution that are not very different from university museums in their activities but are ineligible to be called "museums" under the current definition. A list of all these spaces has been put together, on which we can find university science centers, botanical gardens, showrooms, exhibition halls and also university galleries (including non-collection-based), all of which are institutions that should be discussed and included in the redefinition process. According to Lourenço, we need to start from a general museological definition and slowly make our way towards places that show very little resemblance to the universal common features that define other museums and collections in the fields of natural sciences, anthropology or history.

Once we attempt to define the term itself, we can further examine various types of university gallery, unearthing a potential for more efficient synergies within their activities and studying the different variants of their audience engagement efforts.

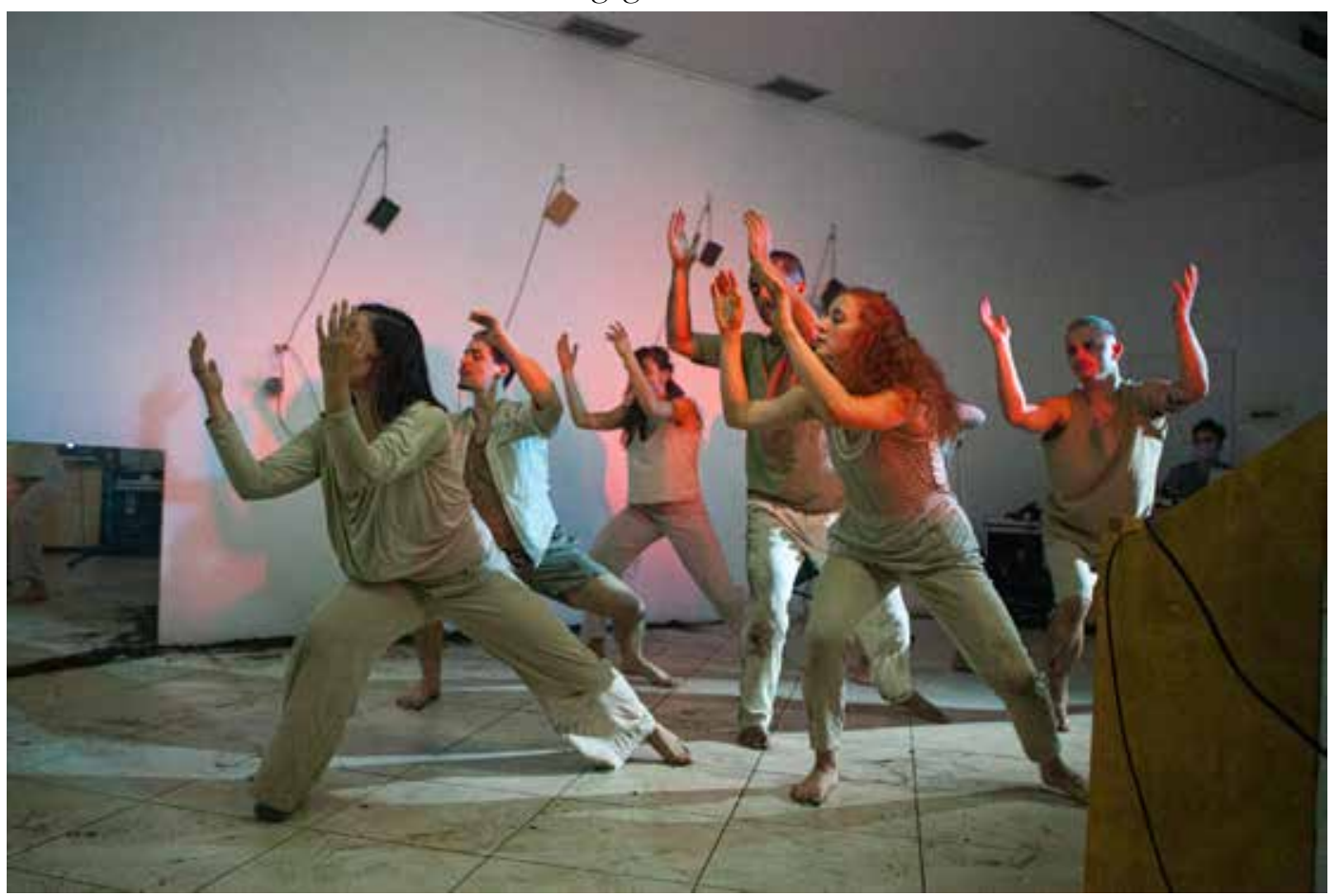

Fig. 1: AMU Gallery. The Academy of Performing Arts in Prague.

University galleries (also known as university art museums) can be defined as collection-based or non-collection-based institutions, established and operated by higher education institutions or their subparts (faculties, studios, departments, etc.). They represent non-commercial spaces that primarily serve as a point of contact between the academic sphere and the general public to the end of presenting art and design. University galleries established by higher education

\footnotetext{
18 "ICOM museum definition has two parts. The first is the one now under discussion, but it is followed by a list of institutions that are eligible to be called museum (science centers are museums, botanic gardens are museums, etc). Galleries are in the list - even galleries without collections, which is problematic. The second note is that I do not think there should be a special museum definition for a university museum (or gallery). I get asked that all the time - what is the definition of university museum - and I believe it should be the same as ICOM's. Otherwise, we would be positioning ourselves outside a system where we fought so hard to belong to."
} 
institutions of both the university type and the non-university type, ${ }^{19}$ such as art academies (e.g., Academy of Performing Arts in Prague, Academy of Fine Arts, Prague, Academy of Fine Arts Vienna), also provide space for public discussion. As is the case with public galleries and museums, the terminological usage of the terms "university gallery" and "university museum" is heavily influenced by the historical, cultural and geographical context.

In order to fully put the given subject matter into the context of its development and into an objective timeframe, the investigated phenomenon of university galleries is assessed from a contemporary point of view. The term "university" in university galleries/museums should be interpreted in its broadest possible sense, as it is meant to encompass all types of higher education institution.

From an ICOM perspective, university galleries are considered to be covered under the common term of "university museums", which in turn fall under the umbrella of MUSEUM. ICOM (and the asscoaited definition). More precisely, the international committee of UMAC, which deals specifically with university museums and collections, sees university galleries as one of the categories and constituents of university museums with a specific focus on art. No exact definition of the term "university galleries" has been proposed so far within UMAC/ ICOM. The importance of defining the term has to do with the need to intensify academic research and investigate the subject matter in more depth. As Sébastien Soubiran, President of the international network UNIVERSEUM, stated, while the phenomenon of "university museums" has received some attention, there has been very little research in Europe dealing specifically with non-collection-based university galleries or exhibition halls. ${ }^{20}$ Defining the term, encouraging its use and applying it in scientific research will improve the visibility and stress the importance of university galleries, not to say all academic cultural heritage, among not only the scientific community but also the public at large.

In literary sources from English-speaking countries outside of Europe, the following terms may be used to denote university galleries:

academic gallery;

college gallery;

campus gallery.

\section{Typology of University Galleries}

As the necessity of self-identification becomes more pressing, it is beneficial to introduce a typology of university galleries, based on extensive research conducted as part of my dissertation. ${ }^{21}$ The different existing archetypes of university galleries have been determined and identified based on several criteria, including exhibition plan quality and frequency, accompanying program frequency, financial and staff structure, exhibition space size and visitor communication. The categorization and definition of these archetypes can facilitate the process of self-identification mentioned above and help both the expert community and the general public set realistic expectations and demands before visiting a particular exhibition space.

From a European as well as global context, university galleries can be categorised into two

\footnotetext{
${ }^{19}$ Typy a druby vysokých škol, accessed February 6, 2021, https://is.muni.cz/do/rect/el/estud/praf/ps13/pravo_vs/ web/04.html

${ }^{20}$ SOUBIRAN, Sébastien, personal communication, June 23, 2019.

${ }^{21}$ GARTNEROVÁ, Eva. University galleries and their potential for international networking. Zlín, 2020. Dissertation thesis. Tomas Bata University in Zlin.
} 
main groups, based on their approach to working with academic heritage: ${ }^{22}$

Collection-based university galleries, i.e., university galleries/art museums that have their own collections. These types of gallery can be found in the United Kingdom, France, Germany and Belgium, as well as outside of Europe. Examples include Yale University Art Gallery, Harvard Art Museums, Ashmolean Museum in Oxford and Fitzwilliam Museum in Cambridge. In the Czech academic sphere, there is currently no university gallery open to the public that preserves and exhibits its art collections. ${ }^{23}$ In addition to exhibitions, collection-based university museums and galleries are mainly engaged in the research and preservation of their collections, which is why they also play an important role in the field of object-based learning. Collectionbased university galleries are mostly bigger in size compared to other types, as they are usually established by larger universities with a longer tradition, they employ a bigger staff, and their facility management is more developed.

Non-collection-based university galleries, that is, exhibition-oriented university galleries that do not have their own collections, based on the concept of exhibition halls, known as Kunsthallen in Germany. These are a popular concept not only in the Czech Republic and Slovakia but also in Poland, Ukraine and other European countries. Representatives of this category can be found all around Europe and include Angewandte Innovation Lab in Vienna, Exhibition Laboratory in Helsinki, designtransfer in Berlin and many others. This type of university gallery has a well-defined staff structure, typically accompanied by a clear division of roles, staffed mostly by academic or administrative employees of the university. They tend to have regular exhibition plans, in which each exhibition cycle is clearly defined in terms of timeframe, topic and orga-

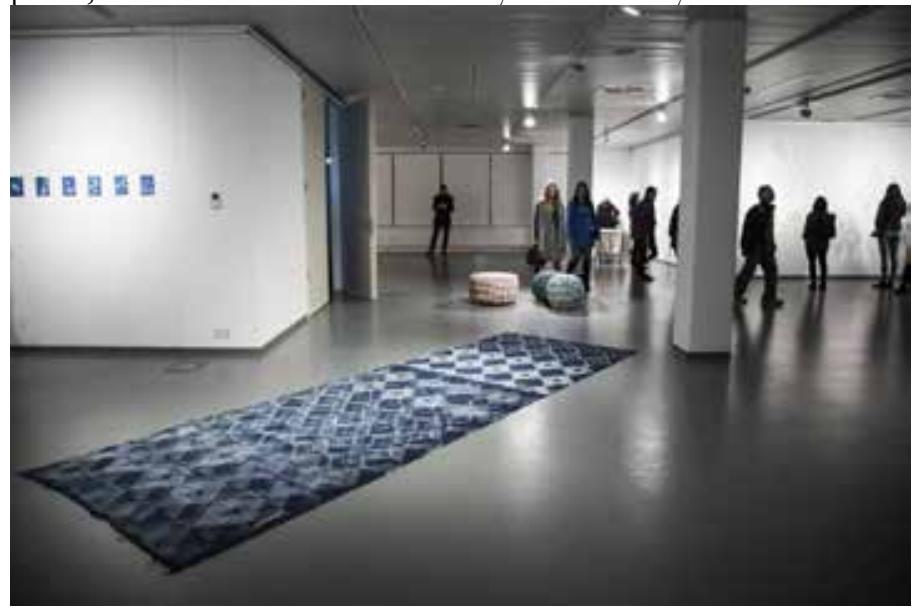

Fig. 2: G18 Gallery. Tomas Bata University in Zlin. nization. Another characteristic feature of these spaces is clear, accountable and visible public communication, usually done through a website, social media or printed materials. In terms of size, non-collection-based university galleries usually operate in larger and more presentable facilities than the experimental university spaces described below, though generally not as large as in the case of university art museums. They tend to have a well-developed accompanying programme for their exhibitions, which translates into good-quality audience engagement. In the context of the Czech Republic and Slovakia, exhibition-oriented galleries include Medium Gallery in Bratislava, Ústí nad Labem House of Arts, G18 Gallery in Zlín or UM Gallery, GAMU and AVU Gallery in Prague.

Although experimental university spaces and projects tend not to be given the label of

\footnotetext{
${ }^{22}$ CO JE GALERIE? Prague: Metodické centrum pro muzea výtvarného umění, 2021, accessed Feburary 8, 2021, http://www.mc-galerie.cz/admin/files/pdf/cojegalerie/CO-JE-GALERIE.pdf

${ }^{23}$ Czech university museums, such as the Mendel Museum of Masaryk University in Brno, Hrdlicka Museum of Man at the Faculty of Science of Charles University in Prague or Fort Science at Palacký University Olomouc, self-identify as "university museums of natural sciences".
} 
galleries by the international gallery community, they deserve a category of their own in the typology of university galleries. They mostly operate on smaller experimental premises (such as a small room or hallway), and their exhibition plans are irregular and/or incomplete, often featuring short and frequent exhibition cycles. The management of these spaces is in the hands of either students or doctorands. Alternatively, academic staff of the university can be put in charge, though their commitment is usually only part-time, as they perform other work-related tasks alongside running such spaces. In most cases, the staff structure lacks any clear definition, and no gallery advisory board or other advisory body has been appointed. These types of space may be less visible and harder to look up, as some of them do not have their own website and public communication is carried out on an irregular basis. Many experimental university projects also lack the time and human resources to organise accompanying programmes and gallery animations. In the context of the Czech Republic and Slovakia, this category is represented by Galerie FSv in Prague, František Vrána Exhibition Hall in Brno and CZU Gallery in Prague. Experimental university spaces can be "experimental" in several different aspects - some might experiment with the concept of space and step out of the traditional "white cube" approach, such as NIKA Gallery, an exhibition space located inside a wall niche in a Prague metro station, or Billboart Gallery, known for presenting art through a billboard; others may experiment with the very concept of exhibition, such as Díky Moc, a rotational photography exhibition programme run by the students of the Studio of Advertising Photography at the Faculty of Multimedia Communications of Tomas Bata University in Zlin that takes place in the students' homes.

The diversity of university gallery concepts demonstrated in the Czech Republic, Slovakia

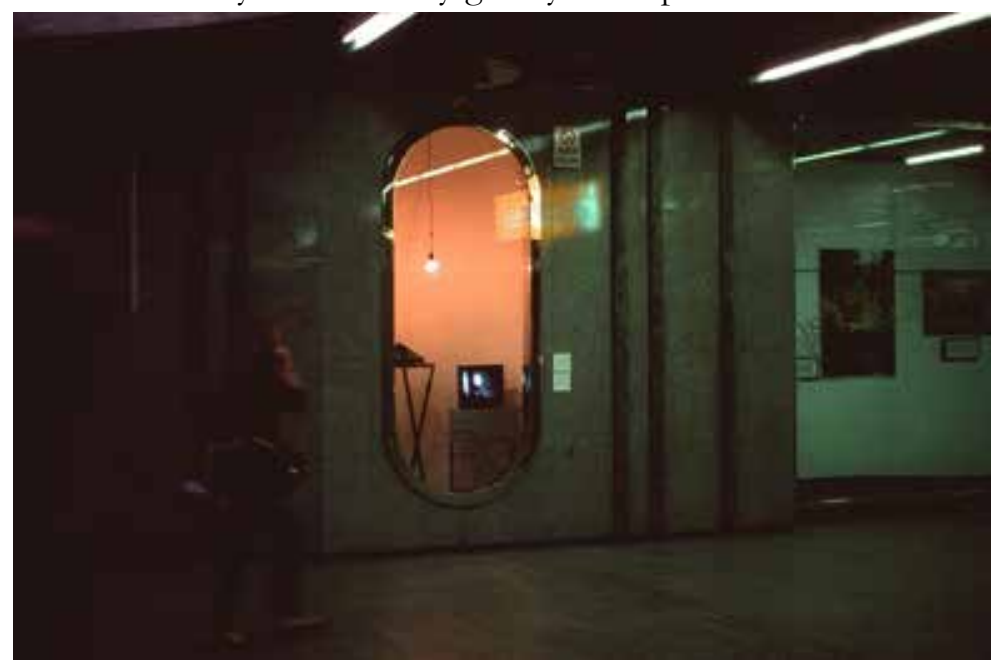

Fig. 3: NIKA Gallery. Academy of Arts. Architecture and Design in Prague. and beyond brings forth the necessity to consider other forms of categorization in our approach to university galleries. An important role is played by the focus of the establishing university, which often reflects the mission and the role that the given university gallery fulfills.

With this in mind, university galleries can be divided into the following categories:

Established by a higher education institution specializing in art or by its subpart (such as faculties, departments, ...) specializing in art. Examples include UM Gallery, FFA Gallery, Ladislav Sutnar Gallery, Ústí nad Labem House of Arts, G18 Gallery and Fx Gallery.

Established by a higher education institution not specialising in art or its subpart (such as faculties, departments, ...) not specializing in art. Examples include Pitevna Gallery orGallery P.

Speaking about different forms of categorization, it is also beneficial to make a distinction 
between university galleries and student galleries.

Student galleries are different from the categories previously mentioned in that they are established by the students of a given university, independently of the academic structure. In order to pursue their gallery activities, students often resort to founding associations or other entities. In their operation, student galleries imitate the functions of university galleries, as is the case withGalerie Podlaha Ostrava or the Photogether Gallery in Zlín. Many of the student galleries denoted as such eventually turn into established exhibition spaces. The stories of Czech independent galleries are documented and presented in Lenka Sýkorovás project, entitled Action Galleries. ${ }^{24}$

Non-collection-based galleries, discussed in detail in the next part of this research paper, are a place for experimenting and presenting the works of students and academic staff on an international stage and, most importantly, a space for public discussion. They are also instrumental in reaching a better understanding of the added value and third mission of universities. Defining university galleries and improving their perception as a component of museum and gallery culture is essential for the mere fact that in this way, they can be categorised and included in general culture statistics, since currently they are often left out and forgotten or even classified under activities with little relation to galleries, which they intrinsically are.

University galleries mostly have a non-commercial character, with the exception of fundraising elements in their financial strategies. It is precisely the absence of the need to sell artwork that gives university gallery exhibitions creative freedom and independence. Jeffrey Taylor ${ }^{25}$ goes so far as to claim that in the US, the network of university galleries serves as a hub for artistic forms which would be unable to exist in the commercial sector.

\section{Role of Non-Collection-Based University Galleries}

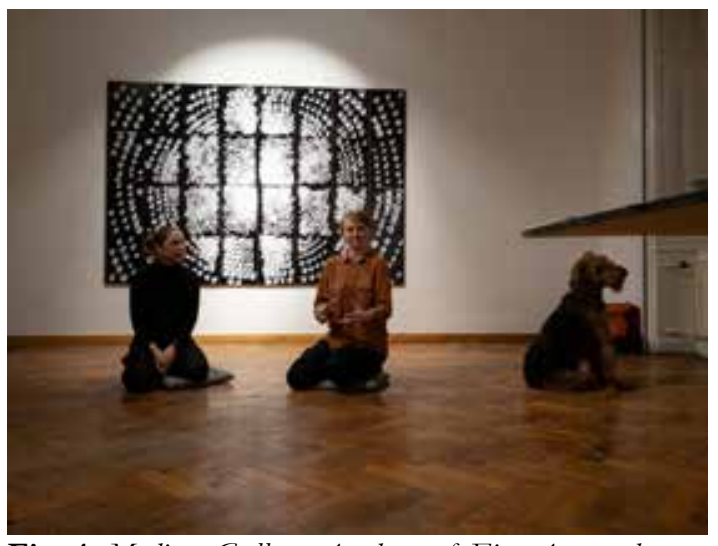

Fig. 4: Medium Gallery. Academy of Fine Arts and Design in Bratislava.

The past two decades have been something of a golden age for non-collection-based university galleries, which has been reflected in the content of their exhibitions as well as the role they perform, and not only within the academic sphere. The topic of university galleries in the Czech Republic is finally at the forefront of discussion, which is demonstrated by the establishment of an academic conference dedicated specifically to university galleries (Univerzitní galerie - Tradice, výstavní praxe a edukační potenciál), whose aim is to "bring attention to the importance of university galleries as a first space in which students of art and art education learn how to present their work, experience how a gallery is run and explore the obstacles of curatorial work." ${ }^{\text {26 }}$

University galleries have demonstrated the ability to realise the ideals that other types of art museum or gallery promote in their missions - especially their commitment to serve as a

\footnotetext{
${ }^{24}$ Action galleries, accessed February 7, 2021, http:/ /www.actiongalleries.info/

${ }^{25}$ TAYLOR, Jeffrey. Visual arts management. New York: Routledge, 2018, p. 51-58)

${ }^{26}$ Held in the period of November 10-11 2020 under the auspices of the Department of Fine Arts and Textile Design, Faculty of Education, University of Hradec Králové.
} 
source of culture for the public and to make art education accessible. In their programmes, communications and open approaches towards audiences, university galleries are as much an equal part of the creative industries and cultural economy as their public counterparts. In many cases, they go so far as to serve as an additional culture tier, complementing the cultural landscape of their hometowns and communities in a way that public institutions might not have the capacity to do. This may be due to their more informal and open atmosphere and the fact that they have to listen to the needs of their audiences twice as hard, as, unlike their public counterparts, they must struggle to convince visitors of their quality and bust the myth of university galleries being mere training grounds for students, with no cultural relevance of their own. As institutions affiliated to universities, university galleries are arranged in such a way that they can educate their visitors about the basic skills associated with any museum, art museum or gallery, which is visual literacy. The ability to "read" art is rarely intuitive. It requires attention and a level of cultivation. ${ }^{27} \mathrm{~A}$ specific feature of university galleries is undoubtedly their interdisciplinarity, as the plethora of study programmes offered by their home universities often serves as an element of enrichment. Differing views on potential topics or activities bring about new knowledge and opportunities for the creation of joint projects and endeavours, with the university gallery serving as a source of inspiration.

In most cases, university galleries are the first place where students can establish a connection with the academic environment and gallery operations (from the point of view of an artist or gallery worker). Starting from potential students and moving outward to other target groups, university galleries can serve as a point of contact with the university for various audiences by giving the general public a reason to step onto the premises of university campuses, which they would otherwise not do.

\section{Projecting the Missions of Universities onto University Galleries}

One more feature that university galleries can benefit from is the academic environment in which they exist, as it gives them creative freedom. In a semi-structured interview conducted as part of my doctoral thesis, Romana Veselá ${ }^{8}$ discusses the first, second and third mission of universities and how these tie in with gallery activities.

The mission of education is fulfilled by university galleries in several ways:

a) Academic fields that are directly or indirectly tied to the gallery exist on two levels. The first level gives students a chance to practice working in a simulated gallery environment and apply theoretical knowledge into practice. Students learn how to use the gallery as a tool for educating and communicating with audiences. These academic fields include curatorial studies, arts management, fine arts and education. The second level serves as an opportunity for students to practice different methods of interpretation and use the gallery as one of the many ways to approach an art object or develop new concepts. These academic fields include art history and museology.

b) Education on current global topics and issues is achieved with every single exhibition or its accompanying programme.

c) In line with the mission of education, gallery educators help adapt the potential of an exhibition to convey a message to the needs of different audience segments and age groups.

\footnotetext{
${ }^{27}$ Boston Review: The Rise of the University Museum, accessed May 13, 2019, http://bostonreview.net/arts-culture/alana-shilling-janoff-university-art-museums

${ }^{28}$ GARTNEROVÁ, University galleries..., p. 68-70)
} 
Important topics are addressed in a gamified form and later contextualised.

d) By providing a platform where different visitor target groups can meet on purpose, they facilitate non-formal and informal education.

e) Individual projects are oftentimes tools for interdisciplinary and intercultural learning.

f) University galleries also play an important educational role in universities of the third age by allowing senior students to stay in close contact with current developments, which are usually reflected very well in art.

The mission of research is severely underdeveloped in Czech and Slovak university galleries. This may have to do with the fact that, unlike many university galleries and art museums abroad, they do not possess their own collections and cultural heritage on which to conduct research. In the Czech Republic, the research outputs of university galleries can be divided into the Register of Art Output (known as RUV) and the Registry of Information About Results (known as RIV). Exhibition-oriented galleries can be involved in academic research in a variety of ways. Primarily, they can serve as a platform for artistic research, since they provide the ideal environment for it.

Contrary to other European countries, Czech and Slovak university galleries have not yet developed a strong and primary connection to the third mission of universities. It is only a matter of time, tempered by their ability to respond to current trends, before these university galleries become strong carriers of this mission. Nowhere else can we find a more ideal place to combine the academic and the public, the formal and the informal and theory and practice, than in university galleries, which are also a hub for interdisciplinary cooperation. It is the unique nature of non-collection-based galleries, which do not center their program around their collections, that provides new options and opportunities in the field of audience engagement and beyond.

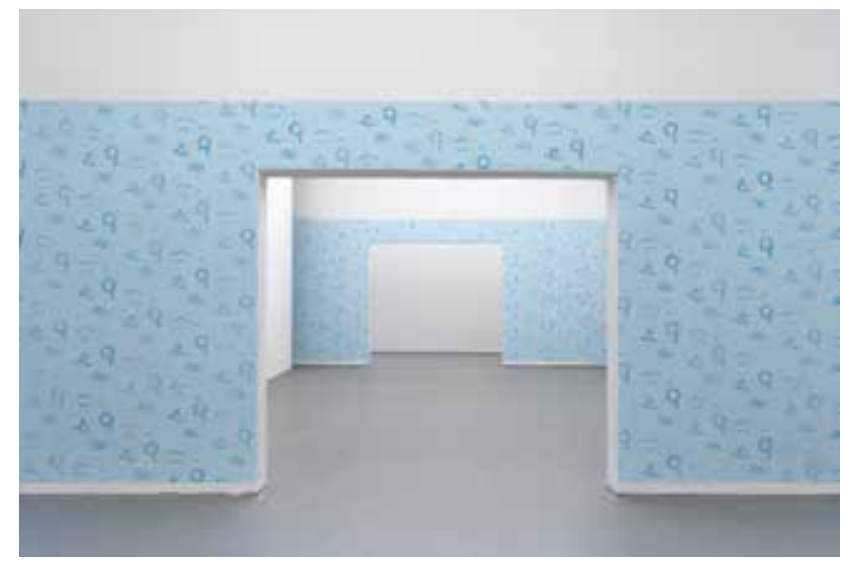

Fig. 5: FFA Gallery, Brno. University of Technology.

\section{Audience and Public Enga- gement}

In most cases, university museums and galleries in the Czech Republic still face the issue of insufficiently diverse audiences that are mostly limited to students, educators, researchers or their close friends. In line with today's museological trend of the visitor being an active centre ${ }^{29}$ of communication and a co-creator exhibition content and accompanying programs in public galleries, it is necessary to penetrate beyond the academic sphere and make communication and content more accessible and adapted to the general public.

Actively engaging university gallery audiences is indispensable. Cultural recipients evolve in parallel with the transformation of the general public's perceptions. The university gallery

\footnotetext{
${ }^{29}$ BOLLO, Alessandro et al. Final Report Study on Audience Development - How to place audiences at the centre of cultural organisations. Brussels: European Commision, 2017.
} 
setting provides an ideal space for the development and experimentation of communication and audience interaction. Fortunately, the number of university galleries that actively deal with audience engagement - ascribing as much importance to the accompanying programs as they do to the actual exhibitions - is growing quickly, as demonstrated in their strategies, missions and activities; this is the case, for example, with Ústí nad Labem ${ }^{30}$ and Zlín. ${ }^{31}$ This way, university galleries have the potential to earn their rightful place as institutions participating in the enrichment of cultural life in their communities and contribute towards an increased decentralization of cultural tourism through their activities.

University galleries should stay up-to-date with current trends in museum and gallery practice, turning audience engagement into a mantra of their existence. They must not be afraid of experimenting, whether they do so by changing their opening hours, using new technologies or switching up their exhibition content.

Generally speaking, university galleries all converge on their interest in stimulating young audiences, who do not necessarily have to come from the ranks of students of the respective university. It is in the best interest of university galleries to attract broader audiences, which can even include students of secondary and elementary art schools in the region, ideal for their specialization, or potential university applicants, for whom the gallery can serve as a platform from which the university can appeal to them. It is therefore not uncommon to see university galleries in the Czech Republic and Slovakia adapt a large part of their activities to this target group. Nevertheless, promotion of these activities forms only a small part of the complex approach of university galleries towards civil society. Educating and cultivating young people, connecting them and motivating them to engage in interdisciplinary cooperation, constitutes

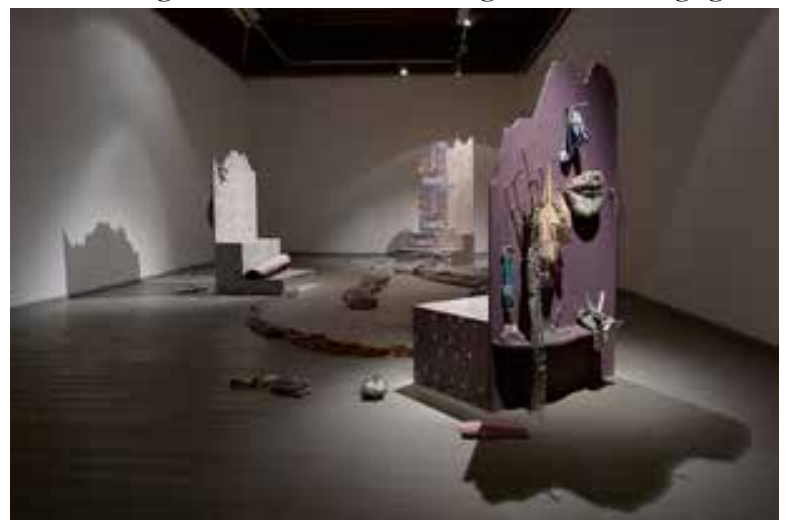

Fig. 6: UM Gallery. Academy of Arts. Architecture and Design in Prague.

the bulk of what university galleries want to offer. For example, the Ústí nad Labem House of Arts offers a diverse portfolio of activities in this regard, such as a screen-printing workshop, gallery animations, guided exhibition tours, educational programmes and a sound workshop, to name but a few.

As far as accompanying programmes are concerned, university galleries are able to cover a wide range of cultural products not necessarily related to the exhibition itself or the exhibition plan in general. University galleries can also organise concerts (UM Gallery in Prague), dances (Medium Gallery in Bratislava), performances (209 Gallery in Brno) and a variety of workshops and lectures covering a diverse range of contemporary issues. University galleries, just as their public museum and gallery counterparts, have already internalised the fact that artwork is no longer the centre of attention of these cultural institutions, as this position has been taken over by the visitor. Extra activities, perceived

\footnotetext{
${ }^{30}$ Ústí nad Labem House of Arts Faculty of Art and Design Jan Evangelista Purkyne University. Accessed February 13, 2021, https://duul.cz/en/usti-nad-labem-house-of-arts-faculty-of-art-and-design-j-e-p-university/

${ }^{31}$ GARTNEROVÁ, Eva. Př́stup k návštěvníkům univerzitních galerií a udržitelnost jejich zapojení. Nenávratné stopy: tradice a udržitelnost jako roční téma galerie G18. In: Irreversible traces: tradition and sustainability as the annual theme of the G18 Gallery. Zlín: Univerzita Tomáše Bati, Fakulta multimediálních komunikací, 2019, (p. 225-241)
} 
as a sort of an "added value" by the public, are used to appeal to visitors and encourage them to visit a particular exhibition.

Many university galleries also focus on working with different target groups by preparing specific programmes or appealing to the elderly, disabled or other groups with specific needs. It is, however, safe to say that efforts to engage special needs and minority audiences could be intensified and produce more activities that would increase the social inclusion of these marginalised groups.

\section{Conclusion}

Non-collection-based university galleries are a part of academic cultural heritage and deserve to be treated equally to other cultural institutions and collection-based university museums by all potential stakeholders. They deserve to be discussed, researched and exposed much more. To this end, this research paper introduced and discussed the topic of non-collectionbased university galleries, one of the first publications with this specific focus in both the Czech Republic and Europe, in order to motivate and inspire other researchers and culture professionals to give the subject more attention and promote the development of university galleries on the levels of awareness, education and research. The study briefly outlined the historical development of university galleries. For the first time in the history of research on noncollection-based university galleries, a typology of these cultural institutions was introduced. Furthermore, the topic of audience engagement was discussed, highlighting the fact that even though these cultural institutions do not possess collections and cannot rely on object-based learning, they can still offer rich and diverse programmes that can contribute to bringing new educational, cultural and entertainment aspects to their public. The underlying survey on which this study is based was conducted by the author in the years 2016-2020, predominantly in the Czech Republic and Slovakia, therefore the study also reported best practices and examples of Czech and Slovak university galleries and their approaches, bringing added value to the field, as little research had been done on the topic in the Central European region.

University galleries help reveal and strengthen the identity, image, uniqueness, significance and also the value of universities. They are a bridge between the academic and the public, performing the role of mediating the university artistic environment to the general public. A university gallery can also express and mirror the historical, cultural or economic context of its university or faculty, as well as the commitment to its vision, mission and philosophy. University galleries can serve as a perfect marketing and communication tool for higher education institutions; apart from fulfilling the third mission of universities, they have the potential to cultivate students, employees and other stakeholders. In their region, they provide a new means of cultural enrichment and contribute to the development of creative industries. They represent a channel that can be used not only by the establishing universities but also by cities, regions or other cultural organizations. University galleries are a phenomenon worthy of attention, and improving their quality should be a priority. I believe that it is necessary to raise public awareness of university galleries as places for art and design that are open to new possibilities. Let us put them on the map of cultural and educational institutions synonymous with success and quality, rather than letting the label of "university" be perceived as another word for "training ground" or "amateur". 


\section{References}

BOLLO, Alessandro (2017). Final Report Study on Audience Development - How to place audiences at the centre of cultural organisations. Brussels: European Commision. ISBN 978-92-79-59149-5.

FRANKENBERG, Pablo. Museum Utopia. A Brief Architectural History of the Ideal Museum. In Art History Supplement, 2(3), May 2012. Accessed online https://www.vonfrankenberg. cc/site/assets/files/1072/museum_utopia_ahs.pdf. ISSN 2046-9225.

GARTNEROVÁ, Eva (2019). Př́stup k návštěvníkům univerzitních galerií a udržitelnost jejich zapojení. In: Irreversible traces: tradition and sustainability as the annual theme of the G18 Gallery. Zlín: Tomas Bata University in Zlin. ISBN 978-80-7454-870-3.

GARTNEROVÁ, Eva (2020). University galleries and their potential for international networking. Zlín: Tomas Bata University in Zlin. ISBN 978-80-7454-942-7.

HASKELL, Francis (2000). The Ephemeral Museum: Old Master Paintings and the Rise of the Art Exhibition. Yale: Yale University Press. ISBN 9780300085341.

KROUPA, Jiří (2010). Metodologie dějin umění. Brno: Masarykova univerzita. ISBN 978-80210-5315-1.

LOURENÇO, Marta (2019). Defining the UNIVERSITY MUSEUM today: Between ICOM and the 'third mission'. Speech given at the meeting 'Il museo in evoluzione verso una nuova definizione', organised by ICOM Italy and the University of Milan, May 8, 2019. Accessed July 10, 2019, http://umac.icom.museum/defining-the-university-museum-today-betweenicom-and-the-third-mission/

PEVSNER, Nikolaus (2014). Academies of art, past and present. United Kingdom:

Cambridge University Press. ISBN 1107421446.

SEMPER, Gottfried (2007). The Ideal Museum: Practical Art in Metals and Hard Materials. Vienna: Schlebrügge. ISBN 9783851600858.

SHILLING-JANOFF, Alana (2014). The Rise of the University Museum: Can Campus Galleries Save the Art Museum? In: Boston Review, November 13, 2014. Accessed May 13, 2019, http://bostonreview.net/arts-culture/alana-shilling-janoff-university-art-museums

TAYLOR, Jeffrey (2018). Visual arts management: a new paradigm for cultural diplomacy and arts management. New York: Routledge. ISBN 978-1-138-68470-6.

WOOD S., Christopher (2019). A History of Art History. United Kingdom: Princeton University Press. ISBN 9780691204765.

Websites: Action galleries. Accessed February 7, 2021, http://www.actiongalleries.info/

CO JE GALERIE? Accessed February 8, 2021, http://www.mc-galerie.cz/admin/files/pdf/ cojegalerie/CO-JE-GALERIE.pdf

Exhibition plan. VSVU: MEDIUM Gallery. Accessed February 13, https://www.vsvu.sk/en/ medium-gallery/exhibition-plan/?v=VOP014OQ

History of The Ashmolean. Accessed February 7, 2021, https://www.ashmolean.org/historyashmolean

ICOM Museum definition. Accessed August 29, 2019, https://icom.museum/en/activities/ standards-guidelines/museum-definition/

ICOM Museum definition. Accessed August 29, 2019, https://icom.museum/en/about-us/ missions-and-objectives / 
Networks. UMAC ICOM. Accessed January 10, 2020, http://umac.icom.museum/resources/ networks/

Princeton University Art Museum. Accessed July 10, 2019,

https://artmuseum.princeton.edu/

The Ashmolean Story. Accessed February 7, 2021, https://www.ashmolean.org/theashmolean-story

The history of The Paintings Gallery. Accessed February 7, 2021, https://www.akbild.ac.at/ portal_en/collections/paintingsgallery/collection/history/the-history-of-the-paintingsgallery?set_language $=$ en\&cl $=$ en

Typy a druhy vysokých škol. Accessed February 6, 2021, https://is.muni.cz/do/rect/el/estud/ praf/ps13/pravo_vs/web/04.html

UMAC: International council of museums committee for university museums and collections. Accessed July 23, 2019, http:/ / umac.icom.museum/

Ústí nad Labem House of Arts Faculty of Art and Design Jan Evangelista Purkyne University. Accessed February 13, 2021, https://duul.cz/en/usti-nad-labem-house-of-arts-faculty-ofart-and-design-j-e-p-university/ 